\title{
Phytosociological survey vegetation map of Sicily (Mediterranean region)
}

\section{Lorenzo Gianguzzi, Fabio Papini \& Dario Cusimano}

To cite this article: Lorenzo Gianguzzi, Fabio Papini \& Dario Cusimano (2016) Phytosociological survey vegetation map of Sicily (Mediterranean region), Journal of Maps, 12:5, 845-851, DOI: 10.1080/17445647.2015.1094969

To link to this article: http://dx.doi.org/10.1080/17445647.2015.1094969
ใ
(c) 2015 Lorenzo Gianguzzi

\section{$+\quad$ View supplementary material ๔}

\section{册 Published online: 14 Oct 2015.}

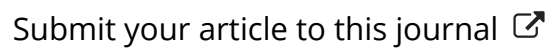

Џ Article views: 132

Q View related articles $\sqsubset$ 


\title{
Phytosociological survey vegetation map of Sicily (Mediterranean region)
}

\author{
Lorenzo Gianguzzi ${ }^{\mathrm{a}}$, Fabio Papini ${ }^{\mathrm{b}}$ and Dario Cusimano ${ }^{\mathrm{a}}$ \\ ${ }^{a}$ Department of Agricultural and Forest Sciences, Università degli Studi di Palermo, Palermo, Italy; ${ }^{b}$ Agristudio S.r.l., Firenze, Italy
}

\begin{abstract}
We present the results of a study aimed at developing a vegetation map of Sicily (Italy) including the smaller circum-Sicilian islands, for an area of approximately $25,703 \mathrm{~km}^{2}$. The work is a synthesis of studies carried out in accordance with the survey methodology of phytosociology in the last 40 years over the whole study area. The vegetation map of Sicily was compiled in a Geographical Information Systems (GIS) environment, in order to produce a cartographic representation at a scale of 1:10,000 (reduced to a scale of 1:250,000). The physiognomic-structural characteristics of the plant landscape of Sicily are analyzed, providing a general and, at the same time, detailed overview of the phytocoenotic aspects represented on the territory, as well as of the relative bibliographic references. At the reference scale, 36 types are represented, 16 of which are related to zonal vegetation (Mediterranean maquis, Quercus ilex woods, Quercus suber woods, Castanea sativa woods, Quercus pubescens deciduous woods, mesophilous deciduous woods, Fagus sylvatica woods, Betula aetnensis woods, woods dominated by woody gymnosperms, forest edge shrubs, orophilous pulvinate shrubs, shrublands and garrigues, Ampelodesmos mauritanicus grasslands, mesophilous and sub-hygrophilous grasslands and pastures), 11 are related to azonal vegetation (riparian, psammophilous herbaceous, chasmo-halophitic, etc.) and 9 are related to anthropogenic vegetation (arable lands and extensive herbaceous crops, vineyards, olive groves and dry cultivation mosaics, hazelnut groves, irrigated citrus groves and orchards, greenhouses, built-up areas).
\end{abstract}

ARTICLE HISTORY

Received 7 October 2014

Revised 26 July 2015

Accepted 1 September 2015

KEYWORDS

Sicily; phytosociology;

vegetation map; GIS; habitat conservation; Mediterranean region

\section{Introduction}

Vegetation maps - produced at different scales $(1: 50,000,1: 25,000$ and $1: 10,000)$, according to the degree of detail - represent phytocoenoses and provide useful quali-quantitative assessments of biological resources in a specific area (Pedrotti, 2004). In preliminary studies for land planning and management, they represent important summary documents, whose graphic design is now performed through Geographic Information Systems (GIS), often applying the survey methodology of Phytosociology (Biondi, 1996; Biondi \& Calandra, 1998; Biondi et al., 2007; Rivas-Martínez, 2005). This paper provides an example of this methodology by compiling a map at a scale of 1:250,000, based on a field survey at a scale of 1:10,000. The surveyed area is Sicily, the largest Mediterranean island $\left(25,432 \mathrm{~km}^{2}\right)$, including its smaller islands (the archipelagos of the Aeolian, Aegadian and Pelagie Islands, Ustica and Pantelleria islands), for a total area of $25,703 \mathrm{~km}^{2}$.

The study is the result of years of research in the area and gives an overview of the extensive phytosociological-cartographic literature on this territory produced in the last 40 years. Some of the main incentives of this research are related to two important laws concerning Sicily: (1) the Regional Law 98/1981, which led to the establishment of 5 natural parks (Mt. Etna,
Madonie Mts., Nebrodi Mts., Sicani Mts. and Alcantara River) and over 70 natural reserves; (2) the Habitats Directive 92/43/EEC, which led to the identification of 234 Natura 2000 sites (205 Sites of Community Importance [SCIs], 15 Special Protection Areas [SPAs], 14 SCIs and SPAs).

The vegetation map of Sicily is a useful synthesis of the regional plant landscape, whose complexity and variety reflect the large physiographic, lithological, geomorphological and bioclimatic variability of the territory. Moreover, this landscape has been affected by human activity, within an area in the centre of historic and cultural events that have characterized the civilization of the whole Mediterranean region.

\section{Study area}

Sicily is in the central part of the Mediterranean Sea, separated from the Italian Peninsula by the Strait of Messina and washed by the Ionian Sea (eastward), the Tyrrhenian Sea (northward) and the Channel of Sicily (southward), which separates Sicily from Africa (Figure 1). The small circum-Sicilian islands are the Aeolian Islands (northeastward), the Ustica Island (northwestward), the Aegadian Islands (westward), the Pantelleria Island (southwestward) and the Pelagie Islands Lampedusa and Linosa (further south). 




Figure 1. Framework of Sicily and its smaller islands in the Mediterranean region.

The landforms of the northern part of Sicily are characterized by mountains that, from east to west, include the Peloritani, the Nebrodi, the Madonie, Palermo and Trapani mountains. The central-southern and south-western parts - with the exception of the Sicani Mountains - show a different landscape, with lower heights and hills. The central-eastern part is dominated by the volcanic cone of the Mt. Etna, southwards of the Peloritani Mountains, whereas the south-eastern part is dominated by the Hyblean Mountains plateau.

The geological history of Sicily is linked to that of a large area of the Mediterranean Sea, characterized by extreme tectonic mobility, mostly defined by sedimentary rocks deposited in different paleogeographic domains, subject to tectonic vicissitudes from the Upper Palaeozoic to the Quaternary. On the basis of petrographic, sedimentological and textural characteristics, and stratigraphic and structural setting, the geological formations of Sicily can be grouped in various lithological complexes (Lucchesi, 2004), which can be summarized as follows: Continental deposition clastic Complex (alluvial deposits, sometimes terraced; coastal, lacustrine and marsh deposits; slope accumulations); Volcanic Complex (Mt. Etna, ancient volcanics of the Hyblean Mts., Aeolian, Ustica and Linosa islands); Clayey-marly Complex (Pleistocene clays, midPliocene blue clays, marls with foraminifera of the lower Pliocene, clayey and marly formations of the middle-upper Miocene, pelitic lithofacies of Flysch deposits, brecciated clays and varicoloured clays);
Evaporitic Complex ('Gessoso-Solfifera' Formation of the Upper Miocene, characterized by Tripoli, sulphur limestones, gypsum and salts); Conglomeratesandstone Complex (terrigenous lithofacies of the mid-upper Miocene); Sandstone-clayey-calcareous Complex (flyschoid formations with a predominant sandstone composition, mainly spread in the northern sector of Sicily); Carbonate Complex (calcareous, calcareous-dolomite and dolomite formations, aged between Mesozoic and Tertiary, which constitute the structure of the Apennine-Maghrebian Sicilian chain, present on the heights of the northern part of Sicily and in the Hyblean area); Phyllitic and shale-crystalline Complex (metamorphic basement of the Peloritani Mts.).

According to the classification of Rivas-Martínez (1985), the territory is divided into the following six bioclimatic belts (Brullo \& Spampinato, 1990): (1) Inframediterranean (annual average temperature: $18-20^{\circ} \mathrm{C}$ ), along the southern slopes of some small islands in the extreme south (Lampedusa, Linosa, Pantelleria) and of Sicily itself; (2) Thermomediterranean (annual average temperature: $16-18^{\circ} \mathrm{C}$ ), circumscribing the coastal and sub-coastal belt of the various insular areas; (3) Mesomediterranean (annual average temperature: $13-16^{\circ} \mathrm{C}$ ), spread over most of the hillysubmountain areas of Sicily and also in the higher parts of some small islands, such as Pantelleria, Marettimo and Salina; (4) Supramediterranean (annual average temperature: $8-13^{\circ} \mathrm{C}$ ), on the highest peaks of the Sicani, the Madonie, the Nebrodi, the Peloritani Mts. 
and of Mt. Etna; (5) Oromediterranean (annual average temperature: $4-8^{\circ} \mathrm{C}$ ) and (6) Crioromediterranean (annual average temperature: $2-4^{\circ} \mathrm{C}$ ), characteristic of the summit of Mt. Etna.

Regarding rainfall, the area is divided into the following regions: semi-arid (annual average rainfall < $350 \mathrm{~mm}$ per year), limited to the Pelagie Islands and some short coastal stretches in the southern part of Pantelleria; $d r y$ (annual average rainfall $=350-600 \mathrm{~mm}$ ), typical of the coastal and sub-coastal belt of Sicily and of the smaller islands; sub-humid (annual average rainfall $=600-1000 \mathrm{~mm}$ ), which includes hilly and submountain areas of Sicily, the peaks of Pantelleria, Marettimo and some Aeolian islands (Salina, Vulcano); humid (annual average rainfall $>1000 \mathrm{~mm}$ ), on the highest peaks of the Madonie, the Nebrodi, the Peloritani Mts. and of Mt. Etna); hyperhumid (annual average rainfall $>1950 \mathrm{~mm}$ ), limited to the highest part of Mt. Etna.

The biogeographic classification by Rivas-Martínez, Penas, and Diaz (2004) puts Sicily in the Holarctic Kingdom, Mediterranean region, western Mediterranean Subregion, Italo-Tyrrhenian Province and Sicilian Subprovince, within which Brullo, Minissale, Signorello, and Spampinato (1996) distinguish two sectors (in turn divided into subsectors and districts), according to the following scheme: (1) Eu-Sicilian Sector (Sicily, Ustica, Aeolian and Aegadian islands): (a) north-eastern Subsector (Aeolian, Madonie, Nebrodi, Peloritani and Etna districts); (b) western Subsector (Aegadian and drepano-panormitano districts); (c) central Subsector (Agrigento and Catania districts) and (d) southern Subsector (Hyblean and camarinopachinense districts); (2) Pelagic Sector (Pantelleria and Pelagie islands): Pelagic Subsector (cosyrense, algusico and lopadusano districts).

\section{Methods}

The drafting of the Main Map required several phases: (1) preparation of a GIS project aimed at creating a 1:10,000 scale graphic, with a comprehensive database, implementing the various thematic layers with georeferenced documents (according to the Gauss-Boaga coordinate system in kilometers); (2) photo-interpretation of the vegetation through digital color orthophotos (programme 'IT 2000 ${ }^{\mathrm{TM}}$ ', carried out throughout the country by the 'Compagnia Generale di Riprese aeree' of Parma, flight MAE 2007, flight Agea 2007, flight ATA0708 RPA, Perugia, Italy, scale 1:20,000) and satellite images in color (Landsat TM, Google Earth $25 \mathrm{~cm}$ pixels), with digital data on the Technical Map of Sicily in 1:10,000 scale (published for the Sicilian Region in 2002, and subsequent updates); (3) cross-checks of various other information layers (maps published for Sicily on vegetation, land use, geology, soil science and bioclimatology); (4) validation of the photo-interpretation of the identified phytocoenotic types, through field survey and verification; (5) digitizing of the results and additional data; (6) phytosociological characterization of the mapped types and preparation of the legend; and (7) production of the final Main Map in 1:250,000 scale, graphic definition and final version printing.

Figure S1 is a schematic lithological map of Sicily (from Fierotti, Dazzi, \& Raimondi, 1988, redrawn), including the smaller circum-Sicilian islands. Figures S2 and S3 show the thematic maps, respectively, of the annual average temperatures and rainfall of the region, produced on the basis of climate data from the Regional Hydrographic Service covering the 1965-1994 period (Drago, 2005).

The phytosociological characterization complies with the methodological criteria of the Sigmatista School of Zurich-Montpellier (Braun-Blanquet, 1932). The syntaxonomic definition of the coenoses was carried out by examining the extensive bibliography related to the area (Gianguzzi \& Minissale, 2007), whose references are reported in the text and in the supplemental materials. In particular, publications aimed at cartographic surveys at the 1:10,000/ 1:25,000 scale, concern the following areas: Mt. Etna (Poli, Maugeri, \& Ronsisvalle, 1983), Capo Passero Island (Pirola, 1965), Mt. Cofano (Barbagallo, Brullo, \& Guglielmo, 1980; Gianguzzi \& La Mantia, 2008), Linosa Island (Brullo \& Piccione, 1980), Pietraperzia (Brullo, Fagotto, Lo Cicero, \& Piccione, 1980), Vendicari (Brullo, Fagotto, \& Marcenò, 1980), Piano Battaglia on the Madonie Mts. (Raimondo, 1980), Filicudi Island (Longhitano, 1983), Parco della Favorita (Buffa, Venturella, \& Raimondo, 1986), Mt. Carcaci Nature Reserve (Gianguzzi, Spennati, \& La Mantia, 2007), Pantelleria Island (Gianguzzi, 1999; Gianguzzi \& La Mantia, 2002a), Mt. Pellegrino Nature Reserve (Gianguzzi, Ilardi, \& Raimondo, 1996; Surano, Gianguzzi, \& Raimondo, 1996), Torre Salsa Nature Reserve (Cammalleri, Gianguzzi, Ilardi, \& Sortino, 1996), Baulì on the Hyblean Mts. (Costanzo, Furnari, Scelsi, \& Tomaselli, 1996), Sughereta di Niscemi (Costanzo, Furnari, \& Tomaselli, 1996), Bosco Ficuzza, Rocca Busambra, Bosco del Cappelliere and Gorgo del Drago Nature Reserve (Gianguzzi, 2004; Gianguzzi \& La Mantia, 2004; Gianguzzi, La Mantia, \& Rigoglioso, 2004), Monte delle Rose (Gianguzzi, La Mantia, \& Marchetta, 2001), Vallone Calagna Nature Reserve (Gianguzzi \& La Mantia, 2002b; Gianguzzi, La Mantia, \& Lo Presti, 2004), Marettimo Island (Gianguzzi, Scuderi, \& La Mantia, 2003), Levanzo Island (Romano, Tobia, \& Gianguzzi, 2006), Pizzo Cane, Pizzo Trigna and Grotta Mazzamuto Nature Reserve (Gianguzzi, Caldarella, \& La Mantia, 2005), Isola Bella and the surrounding area (Minissale, Sciandrello, \& Spampinato, 2005; Sciandrello, D’Agostino, \& Minissale, 2013), 'Torre Manfria' SCI at Gela (Guarino, Minissale, \& Sciandrello, 2008), 'Capo Murro di Porco, Penisola 
della Maddalena e Grotta Pellegrino' SCI at Siracusa (Minissale, Santo, \& Sciandrello, 2011). Other cartographic studies in scale 1:50,000 affected larger areas, including the carbonate massif of the Madonie Mts. (Raimondo, Gianguzzi, \& Schicchi, 1994), the Province of Palermo (Raimondo et al., 2000) and the southeastern part of the Sicani Mts. (Marino, Castellano, Bazan, \& Schicchi, 2005). Further contributions for the regional area equipped with smaller scale maps were published by Tomaselli, Gentile, Pirola, and Balduzzi (1968), Pedrotti et al. (1992), Raimondo, Gianguzzi, Venturella, and Lo Valvo (1992), Geomap (1995) and Blasi (2010), in addition to other phytosociological and cartographic surveys - some of which are unpublished - promoted by the Sicilian Region (Department of Territory and Environment).

The syntaxonomical framework refers to that reported in the Prodromo della vegetazione d'Italia (http://www.prodromo-vegetazione-italia.org/), except some specific references in the text and in the supplemental materials.

\section{Results}

The results obtained through photo-interpretation and field validation allowed the identification of 36 phytocoenotic types, divided in zonal (communities tied to the various bioclimatic belts, in particular maquis, woods, garrigues and semi-natural grasslands), azonal (coenoses typical of habitats conditioned by the substrate, such as cliffs, streams, coastal dunes, etc.) and anthropogenic vegetation (artificial forest plantation, cultivated land, built-up areas and other habitats affected by human activities). The various types are described in detail in the supplemental materials, following the order of the Main Map legend as shown in Table 1.

\section{Conclusions}

An overview of the mapped types, including their extent, divided between the territory of Sicily and its smaller islands, is given in Table 1. The plant landscape is complex and varied, characterized by 36 phytocoenotic categories, in which anthropogenic types prevail; in fact, in addition to the urbanized areas (buildings and out-buildings, with an area of $125,064 \mathrm{ha})$, most of the territory is covered by 'cultivated lands and temporary fallow lands' $(846,470$ ha), followed by 'Olive groves and other dry crops' $(336,528 \mathrm{ha})$, 'Citrus groves and irrigated orchards' (158,592 ha), 'vineyards' (142,558 ha), 'greenhouses' $(15,608 \mathrm{ha})$ and 'Hazel groves' (12,411 ha). In addition to these vegetation aspects, there are also artificial plantations dominated by non-native species, in particular by Pinus halepensis and other conifers $(57,681 \mathrm{ha})$ and by Eucalyptus camaldulensis and/or other broad-leaved species $(42,145 \mathrm{ha})$; these plantations were set up during the last century - especially in Sicily, and to a lesser extent on its smaller islands in order to promote the recovery of the woodlands reduced by human activity.

On the basis of the cartographic analysis, natural wood communities occupy a total area of $174,296.72$ ha (equal to about 6.78\%), of which $172,736.71$ ha is in Sicily and 1560 ha in the smaller islands, mainly in hilly and mountain areas, as well as along streams and rivers. In particular, they are 'deciduous woods of the Quercus pubescens group and other deciduous species' (94,111 ha), 'Quercus ilex woods' (22,561 ha), 'Quercus suber woods' (21,482 ha), 'Fagus sylvatica woods' (16,285 ha) and 'Betula aetnensis woods' (361 ha), 'thermophilous and mesophilous coniferous woods' (7963 ha), 'riparian and dwarf woods, with prevalence of Salix sp. pl., Populus sp. pl. and Platanus orientalis' (overall 32,322 ha), 'dwarf woods of xeric river terraces with Tamarix sp. pl. and/or Nerium oleander' (15,404 ha).

Other phytocoenotic units of naturalistic and landscape importance are represented by shrubs and garrigues, usually present on the margins of wooded areas, divided into: (a) 'shrublands on forest edges with predominance of thorny and deciduous species' (35,717 ha); (b) orophylous cushion-like shrubs, spread on the Madonie Mts. and Mt. Etna (5398 ha); (c) 'shrubs and garrigues on rocky ridges and eroded slopes of carbonate nature' (13,857 ha) and (d) 'shrubs and garrigues on rocky ridges and eroded slopes of silicate nature' (78,147 ha).

Other secondary units widespread both in Sicily and in the smaller islands are the Mediterranean grasslands, with an overall area of 330,039 ha; these are herbaceous communities, used for grazing and regularly affected by wildfires, that characterize large parts of the landscape of the hilly and submountain belts.

Units of azonal vegetation are also numerous and varied across the territory, represented by 'pioneer glareicolous communities of river gravel beds' (6125 ha), "psammophilous communities of sandy coastal stations' (3174 ha), 'chasmo-halophilous communities on sea cliffs with predominance of Crithmum maritimum and Limonium sp. pl.' (2132 ha), 'halophilous communities of lagoons, salt flats and brackish marshes' (3174 ha), 'halo-nitrophilous communities of badlands areas' (14,439 ha), 'hygro-hydrophilous communities of freshwater lakes' (14,496 ha), 'chasmophitic communities of rocky cliffs, including quarry areas and lithic outcrops' (11,138 ha) and 'lava flows and naked lava fields or with sparse vegetation' (16,415 ha).

Thus, the plant landscape of the area is largely anthropogenic, and reflects intense use since ancient times of this important territory situated in the centre of the Mediterranean area. The natural aspects are limited to relatively small 'natural oasis', whose biotopes 
Table 1. Phytocoenotic types surveyed and their extent in Sicily and in the smaller islands.

\begin{tabular}{|c|c|c|c|c|}
\hline Code & Synthetic description & Total area (ha) & Sicily area (ha) & $\begin{array}{l}\text { Smaller islands } \\
\text { (ha) }\end{array}$ \\
\hline 1 & Mediterranean maquis (cl. Quercetea ilicis, ord. Pistacio-Rhamnetalia alaterni) & $21,415.94$ & $18,333.93$ & 3082.01 \\
\hline 2 & Quercus ilex woods (cl. Quercetea ilicis, ord. Quercetalia ilicis) & $22,561.29$ & $21,417.81$ & 1143.47 \\
\hline 3 & Quercus suber woods (cl. Quercetea ilicis, ord. Quercetalia ilicis) & $21,482.58$ & $21,482.58$ & - \\
\hline 4 & Castanea sativa woods (cl. Querco roboris-Fagetea sylvaticae) & $11,539.43$ & $11,518.96$ & 20.47 \\
\hline 5 & $\begin{array}{l}\text { Deciduous woods of the Quercus pubescens gr. and other deciduous species (classes: Quercetea } \\
\text { ilicis, Querco roboris-Fagetea sylvaticae) }\end{array}$ & $68,753.96$ & $68,750.23$ & 3.74 \\
\hline 6 & Deciduous woods with prevalence of other oaks (cl. Querco-Fagetea sylvaticae) & $25,348.73$ & $25,348.73$ & - \\
\hline 7 & Fagus sylvatica woods (cl. Querco roboris-Fagetea sylvaticae) & $16,285.17$ & $16,285.17$ & - \\
\hline 8 & Betula aetnensis woods (cl. Querco roboris-Fagetea sylvaticae) & 361.62 & 361.62 & - \\
\hline 9 & $\begin{array}{l}\text { Coniferous woods: (a) thermophilous pinewoods with Pinus halepensis or Pinus pinaster subsp. } \\
\text { hamiltonii; (b) mesophilous woods with Taxus baccata or Pinus nigra subsp. calabrica }\end{array}$ & 7963.94 & 7571.61 & 392.33 \\
\hline 10 & $\begin{array}{l}\text { Shrublands on forest edges with predominance of thorny and deciduous species (cl. Rhamno- } \\
\text { Prunetea, ord. Pyro spinosae-Rubetalia ulmifolii) }\end{array}$ & $35,717.07$ & $35,696.93$ & 20.14 \\
\hline 11 & Orophylous cushion-like shrubs (Madonie Mountains and Mt. Etna) & 5398.14 & 5398.14 & - \\
\hline 12 & $\begin{array}{l}\text { Shrubs and garrigues on rocky ridges and eroded slopes of carbonate nature (cl. Rosmarinetea } \\
\text { officinalis) }\end{array}$ & $13,857.16$ & $12,243.93$ & 1613.22 \\
\hline 13 & $\begin{array}{l}\text { Shrubs and garrigues on rocky ridges and eroded slopes of silicate nature (cl. Cisto- } \\
\text { Lavanduletea) }\end{array}$ & $78,147.16$ & $72,832.88$ & 5314.28 \\
\hline 14 & $\begin{array}{l}\text { Grasslands of the xeric-mediterranean belt (classes Lygeo-Stipetea and Artemisietea vulgaris) } \\
\text { with: (a) Hyparrhenia hirta; (b) nitrophilous-ruderal species; (c) Brachypodium retusum; (d) } \\
\text { pioneer species of badlands areas; (e) Arundo collina }\end{array}$ & $145,004.02$ & $142,027.39$ & 2976.63 \\
\hline 15 & $\begin{array}{l}\text { Grasslands of the submountain belt (cl. Lygeo-Stipetea), with predominance of Ampelodesmos } \\
\text { mauritanicus }\end{array}$ & $103,282.47$ & $103,259.41$ & 23.06 \\
\hline 16 & $\begin{array}{l}\text { Mesophilous and sub-hygrophilous grasslands of the submountain and mountain belts (classes: } \\
\text { Festuco valesiacae-Brometea erecti, Molinio-Arrhenatheretea) }\end{array}$ & $152,713.86$ & $15,1210.14$ & 1503.72 \\
\hline 17 & $\begin{array}{l}\text { Dwarf woods of xeric river terraces, coastal and sometimes inland (cl. Nerio-Tamaricetea), with } \\
\text { Tamarix sp. pl. and/or Nerium oleander }\end{array}$ & $15,404.83$ & $15,404.83$ & - \\
\hline 18 & $\begin{array}{l}\text { Riparian and dwarf woods of the submountain and mountain river stretches, with prevalence of } \\
\text { Salix sp. pl. (cl. Salicetea purpureae) and Populus sp. pl. (cl. Salici purpureae-Populetea nigrae) }\end{array}$ & $13,793.41$ & $13,768.94$ & 24.48 \\
\hline 19 & Riparian woods with predominance of Platanus orientalis (cl. Salici purpureae-Populetea nigrae) & 3125.19 & 3125.19 & - \\
\hline 20 & Pioneer glareicolous communities of river gravel beds & 6125.78 & 6121.29 & 4.49 \\
\hline 21 & $\begin{array}{l}\text { Psammophilous communities of sandy coastal stations (classes: Cakiletea, Ammophiletea, } \\
\text { Helichryso-Crucianelletea maritimae) }\end{array}$ & 3174.76 & 3120.81 & 53.96 \\
\hline 22 & $\begin{array}{l}\text { Chasmo-halophilous communitites on sea cliffs with predominance of Crithmum maritimum } \\
\text { and Limonium sp. pl. (cl. Crithmo maritimi-Staticetea) }\end{array}$ & 2132.29 & 1055.66 & 1076.63 \\
\hline 23 & $\begin{array}{l}\text { Halophilous communities of lagoons, salt flats and brackish marshes (classes: Ruppietea, Thero- } \\
\text { Suaedetea, Juncetea maritimi, Sarcocornietea fruticosae) }\end{array}$ & 3174.42 & 3142.57 & 31.85 \\
\hline 24 & $\begin{array}{l}\text { Halo-nitrophilous communities of badlands areas (classes: Saginetea, Lygeo-Stipetea, Pegano- } \\
\text { Salsoletea) }\end{array}$ & $14,439.44$ & $14,433.53$ & 5.91 \\
\hline 25 & $\begin{array}{l}\text { Hygro-hydrophilous communities of freshwater lakes (classes: Charetea, Lemnetea minoris, } \\
\text { Potametea pectinati, Phragmito-Magnocaricetea, etc.) }\end{array}$ & $14,496.89$ & $14,496.21$ & 0.68 \\
\hline 26 & $\begin{array}{l}\text { Chasmophitic communities of rocky cliffs, including quarry areas and lithic outcrops (classes: } \\
\text { Asplenietea trichomanis, Parietarietea judaicae, Anomodonto-Polypodietea) }\end{array}$ & $11,138.78$ & $10,857.67$ & 281.12 \\
\hline 27 & Lava flows and naked lava fields or with sparse vegetation & $16,415.09$ & $15,910.80$ & 504.28 \\
\hline 28 & Plantations with predominance (codominance) of Pinus halepensis and other conifers & $57,681.10$ & $56,796.87$ & 884.22 \\
\hline 29 & $\begin{array}{l}\text { Plantations with predominance (codominance) of Eucalyptus camaldulensis and/or other broad- } \\
\text { leaved species }\end{array}$ & $42,145.92$ & $42,137.55$ & 8.37 \\
\hline 30 & Cultivated lands and temporary fallow lands (cl. Stellarietea mediae) & $846,470.20$ & $845,948.17$ & 522.03 \\
\hline 31 & Vineyards (cl. Stellarietea mediae) & $142,558.83$ & $140,386.99$ & 2171.83 \\
\hline 32 & Olive groves and other dry cultural aspects (cl. Stellarietea mediae) & $336,528.59$ & $332,899.29$ & 3629.29 \\
\hline 33 & Hazel groves & $12,411.27$ & $12,411.27$ & - \\
\hline 34 & Citrus groves and irrigated orchards (cl. Stellarietea mediae) & $158,592.85$ & $158,559.34$ & 33.51 \\
\hline 35 & Greenhouses & $15,608.46$ & $15,608.46$ & - \\
\hline \multirow[t]{2}{*}{36} & Buildings and out-buildings & $125,064.91$ & $123,318.57$ & 1746.34 \\
\hline & Total (ha) & $2,570,315.54$ & $2,543,243.47$ & $27,072.07$ \\
\hline
\end{tabular}

fall within protected areas, nature parks and reserves, as well as SCIs (Sites of Community Importance) and SPAs (Special Protection Areas), sparse both in Sicily and in the smaller islands.

\section{Acknowledgements}

The authors gratefully acknowledge Chris Orton for his helpful review that improved the overall quality of the map, Tommaso Caloiero and Giovanni Spampinato for their valuable suggestions and critical review of the paper, and the Editor, Mike Smith, for his helpful advice. The authors are also grateful to the Associate Editor, Colin Pain, for his valuable suggestions concerning the English expression of the manuscript.

\section{Disclosure statement}

No potential conflict of interest was reported by the authors.

\section{Software}

All cartographic work was carried out using the Esri ArcGIS 9.1/10 and Adobe Illustrator CS4. Field data were collected using a Garmin E-Map GPS, with processing by Map Source.

\section{Supplemental data}

Supplemental data for this article can be accessed 10.1080/ 17445647.2015.1094969 


\section{References}

Barbagallo, C., Brullo, S., \& Guglielmo, A. (1980). Carta della vegetazione di Monte Cofano (Sicilia). Esempi di cartografia della vegetazione di alcune aree della Sicilia. Programma finalizzato "Promozione della qualità dell'ambiente", serie AQ/1/39, 43-52. C.N.R. Roma.

Biondi, E. (1996). La geobotanica nello studio ecologico del paesaggio. Annali Accademia Italiana Scienze Forestali, 45, 3-39.

Biondi, E., \& Calandra, R. (1998). La cartographie phytoécologique du paysage. Écologie, 29(1-2), 145-148.

Biondi, E., Catorci, A., Pandolfi, M., Casavecchia, S., Pesaresi, S., Galassi, S., ... Zabaglia, C. (2007). Il Progetto di "Rete Ecologica della Regione Marche" (REM), per il monitoraggio e la gestione dei siti Natura 2000 e l'organizzazione in rete delle aree di maggiore naturalità. Fitosociologia, 44 (2), 89-93.

Blasi, C. (Ed.). (2010). La vegetazione d'Italia con carta delle serie di vegetazione in scala 1:500,000. Roma: Palombi \& Partner S.r.l.

Braun-Blanquet, J. (1932). Plant sociology. New York: McGraw-Hill Book Company.

Brullo, S., Fagotto, F., Lo Cicero, G., \& Piccione, V. (1980). Carta della vegetazione di Pietraperzia. Esempi di cartografia della vegetazione di alcune aree della Sicilia. Programma finalizzato "Promozione della qualità dell'ambiente", serie AQ/1/37, 9-24.

Brullo, S., Fagotto, F., \& Marcenò, C. (1980). Carta della vegetazione di Vendicari (Sicilia). Esempi di cartografia della vegetazione di alcune aree della Sicilia. Programma finalizzato "Promozione della qualità dell'ambiente", serie AQ/1/38, 25-41. C.N.R. Roma.

Brullo, S., Minissale, P., Signorello, P., \& Spampinato, G. (1996). Contributo alla conoscenza della vegetazione forestale della Sicilia. Colloques Phytosociologiques, 24, 635647.

Brullo, S., \& Piccione, V. (1980). Carta della vegetazione di Linosa. Esempi di cartografia della vegetazione di alcune aree della Sicilia. Programma finalizzato "Promozione della qualità dell'ambiente", serie AQ/1/40, 53-66. C.N. R. Roma.

Brullo, S., \& Spampinato, G. (1990). La vegetazione dei corsi d'acqua della Sicilia. Bollettino Accademia Gioenia Scienze Naturali Catania, 23(336), 183-229.

Buffa, M., Venturella, G., \& Raimondo, F. M. (1986). Contributi botanici alla conoscenza del verde storico a Palermo. 2. Carta della vegetazione del Parco della Favorita. Il Naturalista Siciliano, s. 4, 10, 3-90.

Cammalleri, I., Gianguzzi, L., Ilardi, V., \& Sortino, S. (1996). Dati preliminari sulla vegetazione della fascia costiera di Torre Salsa (Sicilia meridionale). Giornale Botanico Italiano, 130(1), 477-477.

Costanzo, E., Furnari, F., Scelsi, F., \& Tomaselli, V. (1996). Vegetazione del territorio di Bauli (Sicilia sud-orientale) con cartografia 1:10,000. Atti $6^{\circ}$ Workshop Progetto Strategico Clima, Ambiente e Territorio nel Mezzogiorno. Taormina, 13-15 Dicembre 1995, 587-605.

Costanzo, E., Furnari, F., \& Tomaselli, V. (1996). La sughereta di Niscemi con carta della vegetazione $(1: 25,000)$ (Sicilia sud-orientale). Atti $6^{\circ}$ Workshop Progetto Strategico Clima, Ambiente e Territorio nel Mezzogiorno. Taormina, 13-15 Dicembre 1995, 563-573.

Drago, A. (2005). Atlante climatologico della Sicilia. Seconda edizione. Rivista Italiana di Agrometeorologia, 2, 67-83.

Fierotti, G., Dazzi, C., \& Raimondi, S. (1988). Commento alla carta dei suoli della Sicilia. Regione Siciliana. Palermo:
Assessorato Territorio ambiente, Università degli Studi di Palermo, Istituto di Agronomia Generale, Cattedra di Pedologia.

Geomap. (1995). Carta dell'uso del suolo. Firenze: Regione Siciliana, Assessorato Territorio e Ambiente, S.E.L.C.A.

Gianguzzi, L. (1999). Vegetazione e bioclimatologia dell'isola di Pantelleria (Canale di Sicilia). Braun-Blanquetia, 22, 1$70+1$ carta (scala 1:20,000).

Gianguzzi, L. (a cura di) (2004). Il paesaggio vegetale della Riserva Naturale Orientata "Bosco della Ficuzza, Rocca Busambra, Bosco del Cappelliere, Gorgo del Drago". Collana Sicilia Foreste, 22, 1-160. Palermo: Azienda Foreste Demaniali della Regione Siciliana.

Gianguzzi, L., Caldarella, O., \& La Mantia, A. (2005). Fitosociologia applicata alla conservazione delle aree protette in Sicilia, la Carta della vegetazione Riserva "Pizzo Cane, Pizzo Trigna e Grotte Mazzamuto" (Monti di Trabia, Sicilia nordoccidentale). Trieste: Congresso Società Italiana di Fitosociologia, Riassunti, 16-17 Febbraio 2005.

Gianguzzi, L., Ilardi, V., \& Raimondo, F. M. (1996). La vegetazione del promontorio di Monte Pellegrino (Palermo). Quaderni di Botanica Ambientale Applicata, 4(1993), 79-137.

Gianguzzi, L., \& La Mantia, A. (2002a). Synphytosociological and ecological analysis of landscape applied to the management of protected areas in Sicily. 1. "Isola di Pantelleria" Natural Reserve. In P. Corona, S. Folving, M. Marchetti (Eds.), Collecting and analyzing information for sustainable forest management and biodiversity monitoring with special reference to mediterranean ecosystems, Proceedings IUFRO conference, 4-7 December 2001 (pp. 65-67). EUR 20392 EN. EC-JRC, Palermo.

Gianguzzi, L., \& La Mantia, A. (2002b). Synphytosociological and ecological analysis of landscape applied to the management of protected areas in Sicily. 4. "Vallone Calagna sopra Tortorici" Natural Reserve. In P. Corona, S. Folving, \& M. Marchetti (Eds.), Collecting and analyzing information for sustainable forest management and biodiversity monitoring with special reference to mediterranean ecosystems, Proceedings IUFRO conference, 4-7 December 2001 (pp. 76-78). EUR 20392 EN. EC-JRC, Palermo.

Gianguzzi, L., \& La Mantia, A. (2004). Le serie di vegetazione della Riserva Naturale Orientata "Bosco Ficuzza, Rocca Busambra, Bosco del Cappelliere e Gorgo del Drago", con allegata carta della vegetazione (scala 1:20,000). Il Naturalista Siciliano, 28(1), 205-242.

Gianguzzi, L., \& La Mantia, A. (2008). Contributo alla conoscenza della vegetazione e del paesaggio vegetale della Riserva Naturale "Monte Cofano" (Sicilia occidentale). Fitosociologia, 45(1), 3-55.

Gianguzzi, L., La Mantia, A., \& Lo Presti, R. M. (2004). Distribuzione, ecologia e status conservativo delle stazioni di Petagnaea gussonei (Sprengel) Rauschert (Apiaceae) nell'area dei Monti Nebrodi (Sicilia nord-orientale). Il Naturalista Siciliano, 28(1), 265-326.

Gianguzzi, L., La Mantia, A., \& Marchetta, P. (2001). Indagini preliminari sul paesaggio vegetale della dorsale di Monte Rose (Monti Sicani, Sicilia centro-occidentale). Atti Congresso Società Italiana di Fitosociologia su "La vegetazione sinantropica. Origine, struttura, ecologia e collegamenti dinamici", Lipari (Isole Eolie) 14-16 Giugno 2001, 63-64.

Gianguzzi, L., La Mantia, A., \& Rigoglioso, A. (2004). Carta della vegetazione (scala 1:20,000) della Riserva Naturale Orientata "Bosco Ficuzza, Rocca Busambra, Bosco del 
Cappelliere e Gorgo del Drago". Il Naturalista Siciliano, 28(1), 205-242.

Gianguzzi, L., \& Minissale, P. (2007). Aggiornamento della lista dei syntaxa segnalati per la Regione Sicilia. In "Lista delle unità sintassonomiche della vegetazione italiana (2000-2004)". Fitosociologia, 44(1), 189-218.

Gianguzzi, L., Scuderi, L., \& La Mantia, A. (2003). Dati preliminari per una caratterizzazione sinfitosociologica e cartografica del paesaggio vegetale dell'Isola di Marettimo (Arcipelago delle Egadi, Canale di Sicilia). Venezia: Congresso Società Italiana di Fitosociologia su "Fitosociologia Applicata", 12-14 Febbraio 2003. Riassunti.

Gianguzzi, L., Spennati, B., \& La Mantia, A. (2007). La carta della vegetazione di Monte Carcaci, Sito d'Interesse Comunitario dei Monti Sicani (Sicilia centro-occidentale) (p. 88). Atti $43^{\circ}$ Congresso Società Italiana di Scienza della Vegetazione, Riassunti. Ancona 25-27 Giugno 2007.

Guarino, R., Minissale, P., \& Sciandrello, S. (2008). Analisi della biodiversità vegetale e relativa cartografia del pSIC "Torre Manfria" (Sicilia meridionale). Quaderni di Botanica Ambientale Applicata, 19, 37-66.

Longhitano, N. (1983). Carta della vegetazione dell'Isola di Filicudi (Isole Eolie). Archivio Botanico Biogeografico Italiano, 58(1-2), 89-105.

Lucchesi, T. (2004). Piano Stralcio di Bacino per l'Assetto Idrogeologico della Regione Siciliana. Relazione generale. Regione Siciliana. Assessorato Territorio e Ambiente. Palermo: Dipartimento Territorio e Ambiente.

Marino, P., Castellano, G., Bazan, G., \& Schicchi, R. (2005). Carta del paesaggio e della biodiversità vegetale dei Monti Sicani sud-orientali (Sicilia centro-occidentale). Quaderni di Botanica Ambientale Applicata, 16, 3-60.

Minissale, P., Santo, A., \& Sciandrello, S. (2011). Analisi geobotanica del SIC "Capo Murro di Porco, Penisola della Maddalena e Grotta Pellegrino" (Siracusa, Sicilia). Fitosociologia, 48(2), 77-98.

Minissale, P., Sciandrello, S., \& Spampinato, G. (2005). Analisi della biodiversità vegetale e relativa cartografia della Riserva Naturale Orientata Isola Bella e del territorio circostante (Taormina - ME - Sicilia). Quaderni di Botanica Ambientale Applicata, 16, 175-208.

Pedrotti, F. (2004). Cartografia geobotanica (p. 248). Bologna: Pitagora Editrice.

Pedrotti, F. (a cura di), Aleffi, M., Biondi, E., Blasi, C., Buffa, G., Canullo, R., ... Venanzoni, R. (1992). Carta della vegetazione reale dell'Italia (scala 1:1,000,000). Firenze: Ministero dell'Ambiente, Relazione sullo stato dell'ambiente. Cartografia Istituto Poligrafico e Zecca dello Stato.

Pirola, A. (1965). Carta della vegetazione dell'isola di Capo Passero (Sicilia sud-orientale). Atti Istituto Botanico
Università Laboratorio Crittogamico Pavia, serie 6, 1, 105-109.

Poli, E., Maugeri, G., \& Ronsisvalle, G. (1983). Carta della vegetazione dell' Etna (in scala 1:50,000). Programma finalizzato "Promozione della qualità dell'ambiente", serie AQ/1/131. C.N.R. Roma.

Raimondo, F. M. (1980). Carta della vegetazione di Piano della Battaglia e del territorio circostante (Madonie, Sicilia). Programma finalizzato "Promozione della qualità dell'ambiente", serie AQ/1/89, 1-43.

Raimondo, F. M., Bazan, G., Gianguzzi, L., Ilardi, V., Schicchi, R., \& Surano, N. (2000). Carta del paesaggio e della biodiversità vegetale della Provincia di Palermo. Quaderni di Botanica Ambientale Applicata, 9(1998), 3160. II, Allegati cartografici (Tav.1-10).

Raimondo, F. M., Gianguzzi, L., \& Schicchi, R. (1994). Carta della vegetazione del massiccio carbonatico delle Madonie (Sicilia centro-settentrionale). Quaderni di Botanica Ambientale Applicata, 3(1992), 23-40.

Raimondo, F. M., Gianguzzi, L., Venturella, G., \& Lo Valvo, M. (1992). Indagine preliminare sul patrimonio biologicoambientale delle coste siciliane. Quaderni di Botanica Ambientale Applicata, 1(1990), 131-182.

Rivas-Martínez, S. (1985). Notions fondamentales de Phytosociologie. Ber. Intern. Symposion. Sintaxonomie in Rinteln, 1-33.

Rivas-Martínez, S. (2005). Notions on dynamic-catenal phytosociology as a basis of landscape science. Plant Biosystems, 139(2), 135-144.

Rivas-Martínez, S., Penas, A., \& Diaz, T. E. (2004). Biogeographic map of Europe (scale 1:16,000,000). Spain: Cartographic Service. University of Leon.

Romano, S., Tobia, G., \& Gianguzzi, L. (2006). Rassegna della flora vascolare dell'Isola di Levanzo (Arcipelago delle Egadi, Canale di Sicilia). Informatore Botanico Italiano, 38(2), 481-502.

Sciandrello, S., D’Agostino, S., \& Minissale, P. (2013). Vegetation analysis of the Taormina Region in Sicily: a plant landscape characterized by geomorphology variability and both ancient and recent anthropogenic influences. Lazaroa, 34, 151-190.

Surano, N., Gianguzzi, L., \& Raimondo, F. M. (1996). La carta della vegetazione del promontorio di Monte Pellegrino. Quaderni di Botanica Ambientale Applicata, 1, 131-182.

Tomaselli, R., Gentile, S., Pirola, A., \& Balduzzi, A. (1968). Carta della vegetazione naturale potenziale della Sicilia (prima approssimazione) (scala 1:500,000). Pavia: C.N.R. Gruppo Ricerca Conservazione Agrobiologia Suolo. 